tively per $\mathrm{kg} \mathrm{DM}$ ). In addition to the cereal, the four diets contained soyabean meal and a mineral and vitamin mixture. They were offered to 96 animals between 23 and $103 \mathrm{~kg}$ liveweight according to a feed restriction plan.

The feed efficiency of the diet based on maize was similar to that of the diet based on low tannin sorghum. Conversely, it was reduced by 3.1 and 7.9 p. 100, respectively with the other two diets.

In a second trial also made in feed restriction conditions a large number of animals per diet (48) was used to determine the difference between a diet based on maize and a diet based on low tannin sorghum $(2.3 \mathrm{~g} / \mathrm{kg} \mathrm{DM})$. Maize and sorghum were supposed to have the same energy value (3950 Kcal DE/ kg DM). Similar growth performance were observed with both diets thus confirming this hypothesis.

\title{
Use of moist grain maize with cobs in bacon pig feeding
}

\author{
J. CASTAING *, R. COUDURE *, F. GROSJEAN ** \\ *A.G.P.M., 122, boulevard Tourasse, 64000 Pau \\ *: I.T.C.F., 8, avenue du Président-Wilson, 75116 Paris
}

France

Two trials were made to compare the use of different grain maize silages including cobs or not (harvest 1982). Bacon pigs were fed according to a feed restriction plan supplying the same amount of dry matter in each diet. In the first trial, a grain maize silage (37 p. 100 moisture) was compared to two silages including cobs (CCM) ${ }^{*}$ ) and with a moisture content of 41 and 48 p. 100, respectively. Both CCM silages led to similar growth and carcass performance. As compared to the cob free diet, CCM reduced the growth rate and deteriorated the feed conversion ratio by $6.2 \mathrm{p}$. 100 , decreased the carcass yield by 0.5 point and improved the lean percentage by 1.5 point.

In the second trial we compared a grain maize silage to two CCM silages including almost 50 and $90 \mathrm{p} .100$ of the cobs and to a silage of whole ears without husks. The last two silages decreased the growth rate by 4.9 and 7.4 p. 100 as compared to the control diet, but increased the muscle percentage of the carcasses by one point. The carcass yield was the same whatever the diet.

These results were compared to those of three trials made in 1981. As compared to a grain maize silage alone, CCM (with the same moisture content) deteriorated the feed conversion ratio by 0.61 p. 100 on an average per point of cobs in the silage.

\section{Utilization of hydrolysed lactose by the pig}

\author{
C. FEVRIER, D. RANDRIANARIJAONA \\ I.N.R.A., Station de Recherches sur l'Elevage des Porcs, \\ Saint-Gilles, 35590 L'Hermitage \\ France
}

The nutritive value of lactose hydrolysed at the rate of $80 \mathrm{p} .100$ by passage on resins at $90-95^{\circ} \mathrm{C}$ (La Prospérité Fermière) was studied during two experiments. Protein and energy balances were measured in 16 Large White castrated male pigs of about $70 \mathrm{~kg}$

(*) CCM : Corn Cob Mix. 
live weight, distributed into 4 groups, 1) a control standard diet, 2) diet RB, without lactose, 3) RB + lactose powder, 4) RB + hydrolysed lactose syrup. The amount of lactose in groups 3 and 4 represented $50 \mathrm{p} .100$ of the daily dry matter intake. The chemical compositions of diets 1,3 and 4 were quite similar apart from the crude energy level which was $100 \mathrm{Kcal} / \mathrm{kg}$ lower in diets 3 and 4 . The apparent digestibility of energy was not statistically different for the 3 diets, i.e. $83.7,80.3$ and $84.5 \mathrm{p}$. 100 , respectively, but that of protein was lower in group 3 (75.4 as compared to 85.5 and 87.9 in groups 1 and 4 , respectively). The digestible energy content was significantly lower in diet 3 as compared to diets 1 and 4 . On the other hand, the metabolisable energy level was lower in diet 4 as compared to the two others. The energy content of lactose was calculated on the basis of the energy values of diet RB in group 2: lactose powder $D E=3078$ $\pm 141 ; \mathrm{ME}=2895 \pm 106$; hydrolysed lactose syrup : $\mathrm{DE}=3608 \pm 75 ; \mathrm{ME}=2806$ \pm 99 . Thus the advantage of hydrolysis is annihilated by the urinary excretion of galactose representing 19 p. 100 of the ingested galactose. Accordingly, these energy values are only valid for an incorporation level of 50 p. 100 of the diet dry matter as the excretion decreases with this level.

The second experiment was made with 56 castrated males and females weighing $57 \mathrm{~kg}$ on an average, distributed into 4 groups and fed the same diet as the previous ones, i.e. diet 1 in group $A, 3$ in group $B, 4$ in group $C$ and diets 1,3 and 4 alternatively by periods of 14 days, in group D. Until $107 \mathrm{~kg}$ live weight, growth rates of groups $\mathrm{B}$, $C$ and $D$ receiving lactose (hydrolysed or not), were significantly lower than that of group A, but similar for the three groups. Alternating diets 1,3 and 4 did not significantly change the growth rates in spite of more days with diarrhoea when diet 3 was offered. At that stage, 3 animals of each sex were slaughtered in each group. Lactose, hydrolysed or not, led to a reduction of the slaughter yield; the increase in lean percentage was not significant. The last 4 males were fattened for a mean period of 129 days during which a non significant difference was observed in the growth rate, i.e. $603 \mathrm{~g} / \mathrm{d}$ in group $\mathrm{C}$ and $693 \mathrm{~g} / \mathrm{d}$ in group $\mathrm{A}$. The lean contents were similar. The last 4 females were inseminated. Two were not fertilized, one in group $\mathrm{C}$ and one in group D. They were sacrificed between day 110 and 113 of gestation. The live weight gains of the sows fed with lactose were not significantly different the one from the others, but they were lower than that of the control group. The gestation net gains or number of foetuses were not different either between the different groups. However, the small number of sows used does not allow us to generalize the results. Cataract was observed in two sows of group $C$ and in 2 of their foetuses.

\title{
Effects of high protein and lysine levels for the supplementation of whey in growing-finishing pig diets
}

\author{
C. FEVRIER *, M. JOST **, M. CHENUZ *** \\ * I.N.R.A., Station de Recherches sur l'Elevage des Porcs, \\ Saint-Gilles, 35590 L'Hermitage \\ France. \\ *: Station fédérale de Recherches sur la Production animale, \\ Grangeneave, CH-1725 Posieux (Fribourg) \\ Suisse \\ ***: Institut cantonal agricole de Grangeneave, \\ CH-1725 Posieux (Fribourg) \\ Suisse
}

A total of 48 Large White pigs (castrated males and females) with a mean live weight of $24 \mathrm{~kg}$ were distributed into 4 groups and fed diets including liquid hard cheese whey in increasing amounts with age $(20$ to $40 \mathrm{p}$. 100 of the dry matter). Using current raw materials, the least expensive feed supplements (different for each group) were used according to a factorial combination of 2 crude protein levels and 2 total iysine levels. In the final diets (whey + feed supplement) the protein levels ranged from 17.0 to 